\title{
Managing Tertiary Education for Peace and Conflict Resolution in Nigeria
}

\author{
Iniobong Ekong Nkang ${ }^{1} \&$ Christopher S. Uwah ${ }^{2}$ \\ ${ }^{1}$ Department of Curriculum Studies, Educational Management and Planning, Faculty of Education, University of \\ Uyo, Uyo, Nigeria \\ ${ }^{2}$ Institute of Education and Professional Development, University of Uyo, Uyo, Akwa Ibom State, Nigeria \\ Correspondence: Iniobong Ekong Nkang, Department of Curriculum Studies, Educational Management and Planning, \\ Faculty of Education, University of Uyo, Uyo, Nigeria.
}

Received: May 28, 2021

doi:10.5430/ijhe.v10n3p295
Accepted: June 21, 2020

Online Published: June 25, 2021

\begin{abstract}
Peace is a necessary condition for the sustainable development of any nation. It is described as the absence of physical and structural violence, and the presence of justice. Peace education involves human rights and conflict resolution education. This justifies the prominence of peace and conflict resolution education in the educational agenda of nations. Based on this, the paper examines the management of tertiary education for peace and conflict resolution in Nigeria. The population of the study comprised lecturers from the Faculty of Social and Management Sciences from the Universities of Benin, Port Harcourt, Calabar and Uyo, totalling 2312. A sample of 231 lecturers was drawn for the study using the Cluster Sampling Technique. One research question and one null hypothesis were considered in this study. Data collection was done using a structured instrument tagged, "Managing Tertiary Education for Peace and Conflict Resolution" (MTEPCR) Questionnaire. The Instrument was duly validated and tested for reliability using the Cronbach Alpha reliability formula. This gave a reliability coefficient of 0.81 . Descriptive statistics such as mean, standard deviation, and simple percentage were used to answer the research question. The null hypothesis was tested at 0.05 alpha level, the one-way ANOVA. The result of the study indicated a low extent in the implementation of peace and conflict resolution education in tertiary institutions. There was no substantial difference in the implementation of peace and conflict resolution education among four federal universities. Based on these findings, key policy, practice and research implications are discussed.
\end{abstract}

Keywords: conflict, conflict resolution, peace education, resolution, tertiary institutions

\section{Introduction}

Conflicts develop when one party's actions are seen to be hindering or blocking the goals, needs, or actions of another. Conflicts are typically associated with negative traits and situations that lead to inefficiency, ineptness, or dysfunctional consequences (Owan, 2018). However, in some cases, it can foster inventive issue solving and improving the situation for all parties involved (Adesanya et al., 2018). It is quite obvious that the human resources of any organization (school) consist of people with diverse cultural, religious, social, political and economic background. This is shown in their attitude to work, temperament and frame of reference, which certainly makes their control often complex for secondary school administrators (Owan \& Agunwa, 2019).Due to the differences among workers in tertiary institutions, conflict is bound to occur. This is because conflict is inevitable in any organization (Arop et al., 2018). However, to promote peace, unity, and synergy among workers, there is a need for appropriate resolution strategies to be adopted by managers.

Recent happenings in nations presuppose that peace and conflict resolution studies should be given prior attention in tertiary educational institutions. The globe has seen waves of international terrorism that have claimed the lives of countless innocent people for religious, ethnic, or political reasons (UNDP, 2016). According to the Global Terrorism Index (2015), Afghanistan, Syria, Iraq, Pakistan, and Nigeria accounted for 78 per cent of all terrorism-related deaths in 2014. According to the same research, since 2000, just $7 \%$ of all cases of terrorism-related attacks have happened in OECD nations, accounting for only 5\% of all instances. In Africa, inter-ethnic conflicts are a common trend. For example, the 2020/2021 war between the Anglophone and Francophone sections of the Republic of Cameroon; the civil war in South Sudan began in 2013 and has claimed the lives of over 50,000 citizens. 
Famine was declared in South Sudan during the first few months of 2017, with nearly five million people at risk from food insecurity. According to Reuters Report in February 2021, the U.N.'s Commission on Human Rights released a report on South Sudan showing that attacks against civilians intensified in 2020. A commission member said the scale of violence and weapons suggested the involvement of state forces or external actors

Nigeria, known for its heterogeneity, cultural diversity and ethnic variation, has not been without the issues of ethnic conflicts among various tribes and regions, terrorism and mayhems. Boko Haram has caused terrible instability, poverty, displacement, and severe misery in Nigeria's underdeveloped and dry North-East area since 2009. Even though the Nigerian government and military deployed against the organization between 2015 and 2018, instability and bloodshed have not only persisted but have risen since then (Felbab-Brown, 2020). Following the Second World War, the establishment of the United Nations (UN) gave impetus for systematic methods to the study of peace and conflict resolution across the world (Ramsbotham, Woodhouse, \& Miall, 2016). The new emergency, and instances of instability challenges (for example, murder, political thuggery and emergency, grabbing, furnished theft, blasting, aggressiveness, ceremonial assassinations, scammers - 419, consensual emergency, dehumanization, pipeline dredging, among others) in Nigerian culture that continues to attract the attention of many countries, governments, and individuals(Ofojebe, 2014).According to Sani (2013), the Nigerian culture is constantly confronted with many crises that are crippling its economy and solidity. Such circumstances cause clans to split and tight meetings to break down, undermining national unity.

Many universities and other institutions of higher learning throughout the world have developed an interest in the issue of peace and conflict resolution in this respect (PCR). Scholars from a variety of disciplines, as well as many powerful politicians throughout the world, continue to agree on the relevance of studies of peace and conflict resolution, as they have for many years. Peace and conflict studies is a social science field that identifies and analyses violent and nonviolent behaviours as well as the structural mechanisms attending conflicts (including social conflicts) to understand those processes which lead to a more desirable human condition (Duncan, 2008; Jeong, 2017). From the above, peace education can be defined as the process of acquiring the values, the knowledge and developing the attitudes, skills, and behaviours to live in harmony with oneself, with others, and with the natural environment. Peace and conflict studies are well established within the social sciences in some universities. Peace Studies allow one to examine the causes and prevention of war, as well as the nature of violence, including social oppression, discrimination and marginalization. Through peace studies, one can also learn peace-making strategies to subdue conflicts and transform society to attain a more just and peaceful society.

Considering the state of affairs in the country, the sustainable national development of Nigeria presupposes the incorporation of peace and conflict studies in the curriculum of tertiary education in the country. There are numerous United Nations declarations on the importance of peace education (Brigg, 2020; Page, 2008). Since the early decades of the 20th century, "peace education programmes around the world have represented a spectrum of focal themes, including anti nuclearism, international understanding, environmental responsibility, communication skills, non-violence, conflict resolution techniques, democracy, human rights awareness, tolerance of diversity, coexistence and gender equality, among others (Groff \& Smoker, 1996; McLeod \& O’Reilly, 2019).Some scholars have also addressed spiritual dimensions of inner harmony or synthesized a number of the foregoing issues into programmes on world citizenship (Huda et al., 2020; Kishino \& Takahashi, 2019; Woiwode et al., 2021).

Several scholars have advocated for the inclusion of conflict resolution skills in teacher education curricula in Nigeria (Akande et al., 2021; Nwaubani \& Okafor, 2015; Omeje, 2015; Sulaiman, 2016; Ubogu, 2016). However, experts believe that peace education should not be treated as a separate subject (Harris 2004) and that teachers' attitudes are crucial in fostering peace in the classroom (Mishra 2011). Several empirical studies abound on peace and conflict resolution internationally and within the context of Nigeria. The study of McLeod and O'Reilly (2019) assessed the criticality of peace and conflict studies from a feminist perspective. The study emphasized the potential for feminist theories, concepts, methodologies, and empirical discoveries to push the boundaries of critical PCS, opening the way for a much more gendered critical PCS.Ashraf and Huma's (2019) study looked at the professional development requirements of elementary school teachers in Khyber Pakhtunkhwa to teach peace. Overall, the survey shows high support for peace education. The idea of introducing peace education at the school level was met with enthusiasm, openness, and receptivity by respondents. Teachers' efficacy in teaching peace principles through topic teaching within a time restriction was also demonstrated by the study. The researchers reasoned that training primary school teachers to incorporate peace education into their regular lessons would be a good first step toward a successful implementation. 
Research conducted at Mutare Teacher's College in Manicaland by Shumba et al. (2005) focused on how teachers' education addressed concerns of growing up and sexual development. The investigation discovered minimal evidence of the institution teaching information on interpersonal relationships, which is one component of conflict resolution. Maduewesi studied how teachers in Nigeria perceive the utilization of teacher education curriculum content for conflict resolution in 2019. The t-test statistical approach was used to analyze data obtained from 31 teacher educator lecturers. The study found that both male and female lecturers agreed that the contents of the teacher education curriculum might be utilised for conflict resolution in Nigeria. According to the findings, material in the teacher education curriculum should include self-control, self-sacrifice, transparency, collaboration, accountability, selflessness, equity, exemplary leadership, social justice, and patriotism, among other things.

Akande (2018) reported the findings of a survey that was conducted to explore teachers' attitudes toward peace education. Primary data was collected from 43 teachers in the Ilorin-South local government region of North-Central Nigeria using a quantitative technique. Teachers are fully aware of the need for peace education but lack the skills and resources to effectively conduct a program of this kind, according to the results. The study recommends that educators participate in peace education workshops, with the form of such interventions being determined by qualitative research on teachers' attitudes toward peace.Okeke (2018) investigated teachers' perceptions on the impact of peace education in secondary schools in South-East Nigeria. The study's findings suggest that teaching peace education in the classroom can help shape students' attitudes and behaviour; the importance of peace education is undeniable for the cultivation of a safe and prosperous future for the entire world; causes of the crisis in Nigeria include the country's democratic government and its multi-ethnic nature. The disparity in the pupils' backgrounds, on the other hand, was overlooked as one of the crises' causes.

Yunus (2020) experimented with the integration of peace education directly into Islamic religious and citizenship education. The findings show that including peace education directly into the two disciplines improves students' knowledge of peace. The findings also showed that direct integrative teaching of peace education has similar outcomes to direct integration into Islamic education. It also had a substantial impact on pupils' perceptions of peace. The review of existing literature on peace and conflict resolution reveals a growing body of research. However, many cited studies have focused mainly on the benefits of integrating peace education into the education sector (e.g., Maduewesi, 2019; Okeke, 2018; Yunus, 2020). However, the extent to which tertiary institutions have complied with the integration of peace and conflict resolution education into the curriculum seems to have been under-researched. The present study builds on this gap and has been designed to question the state of tertiary institutions in Nigeria and their readiness to promote peace and conflict resolution capacities among students for social acceptance and ethnic tolerance.

\subsection{Purpose of the Study}

The study was carried out to examine the management of tertiary education for peace and conflict resolution in Nigeria. Specifically, the study sought to:

1. Examine the level of integration of peace and conflict resolution education into tertiary education curriculum in Nigeria.

2. Assess the institutional variation in the implementation of peace and conflict resolution education among the selected tertiary institutions.

\subsection{Research Question}

What are the aspects of peace and conflict resolution education currently implemented in the tertiary education curriculum of Nigeria and to what extent?

\subsection{Research Hypotheses}

There is no significant institutional variation in the implementation of peace and conflict resolution education among the selected tertiary institution.

\section{Methodology}

The survey design was adopted for the study. The population comprised male and female lecturers from the faculty of social and management sciences from the Universities of Benin, Calabar, Port Harcourtand Uyo, totalling 2312 (1303 males and 1009 females). A sample of 231 lecturers (130 males and 101 females) was drawn for the study using the Cluster sampling technique. Data collection was carried out with a researcher-developed instrument tagged "Managing Tertiary Education for Peace and Conflict Resolution Questionnaire (MTEPCR). The instrument was designed with two sections. Section A of the instrument was designed to collect information on the respondents' 
demographic variables such as age, gender, educational institutions, qualification and duration of service. Section B of the questionnaire had a total of 19 items, organised on a four-point rating scale. Response options in section B of the instrument ranged from Strongly Agree to Strongly Disagree.

The instrument was subjected to face and content validity by five independent assessors who were experts of peace and conflict studies, as well as, experts of measurement and evaluation. The assessors evaluated the clarity, adequacy and relevance of the items and also made suggestions that were instrumental in developing the final draft of the instrument. For reliability, a trial test was carried out on 30 academic staff of universities who are a part of the population but not the sample. The administration was done once; collected data were subjected to a reliability analysis using the Cronbach Alpha reliability approach.A reliability coefficient of .81 was obtained for the instrument, indicating that the instrument was internally consistent for data collection. Copies of the instrument were administered to the respondents at the various institutions, with the aid of five trained research assistants. All the subjects participated voluntarily after a detailed explanation about the research was made. Collected data were prepared, coded and analysed using descriptive and inferential statistics such as mean, standard deviation, simple percentage and the one-way analysis of variance.

\section{Results}

The results of this study are presented in line with the research question and null hypotheses earlier formulated. In determining the aspects of peace and conflict resolution education currently implemented in the tertiary education curriculum of Nigeria and the extent of their implementation, descriptive statistics were used. The researcher used extant literature in related areas to present a pool of peace and conflict resolution areas for respondents to rate the extent of implementation in their universities. The rating was based on their perception and the result of the analysis is summarized in Table 1.The result in Table 1, revealed generally that there is a low extent in the implementation of peace and conflict resolution education in tertiary institutions. This is because the overall mean value of $2.50 \pm 1.12$ is less than the criterion mean value of 3.00. On a specific note, all the aspects of peace and conflict resolution education were revealed to be implemented to a low extent respectively.

Table 1. Extent of the implementation of aspects of peace and conflict resolution education in the tertiary education curriculum of Nigeria

\begin{tabular}{|c|c|c|c|c|c|c|c|}
\hline \multirow[b]{2}{*}{$\mathbf{S} / \mathbf{N}$} & \multirow[b]{2}{*}{$\begin{array}{l}\text { Aspects of peace and conflict } \\
\text { resolution education }\end{array}$} & \multicolumn{5}{|c|}{ Extent of implementation } & \multirow[b]{2}{*}{ Remark } \\
\hline & & $\begin{array}{c}\text { HI } \\
(\%)\end{array}$ & $\begin{array}{c}\text { I } \\
(\%)\end{array}$ & $\begin{array}{l}\text { NI } \\
(\%)\end{array}$ & $\begin{array}{l}\text { HNI } \\
(\%)\end{array}$ & $\begin{array}{l}\text { Extent } \\
(\bar{X} \pm \sigma)\end{array}$ & \\
\hline 1 & Love and oneness & $\begin{array}{c}55 \\
(23.8)\end{array}$ & $\begin{array}{c}70 \\
(30.3)\end{array}$ & $\begin{array}{c}54 \\
(23.4)\end{array}$ & $\begin{array}{c}52 \\
(22.5)\end{array}$ & $2.45 \pm 1.09$ & Low extent \\
\hline 2 & Religious/Ethnic Tolerance & $\begin{array}{c}52 \\
(22.5)\end{array}$ & $\begin{array}{c}57 \\
(24.7)\end{array}$ & $\begin{array}{c}64 \\
(27.7)\end{array}$ & $\begin{array}{c}58 \\
(25.1)\end{array}$ & $2.55 \pm 1.10$ & Low extent \\
\hline 3 & Sex education & $\begin{array}{c}60 \\
(26.0)\end{array}$ & $\begin{array}{c}51 \\
(22.1)\end{array}$ & $\begin{array}{c}64 \\
(27.7)\end{array}$ & $\begin{array}{c}56 \\
(24.2)\end{array}$ & $2.50 \pm 1.12$ & Low extent \\
\hline 4 & Democracy education & $\begin{array}{c}51 \\
(22.1)\end{array}$ & $\begin{array}{c}67 \\
(29.0)\end{array}$ & $\begin{array}{c}58 \\
(25.1)\end{array}$ & $\begin{array}{c}55 \\
(23.8)\end{array}$ & $2.51 \pm 1.08$ & Low extent \\
\hline 5 & Justice education & $\begin{array}{c}58 \\
(25.1)\end{array}$ & $\begin{array}{c}54 \\
(23.4)\end{array}$ & $\begin{array}{c}66 \\
(28.6)\end{array}$ & $\begin{array}{c}53 \\
(22.9)\end{array}$ & $2.49 \pm 1.10$ & Low extent \\
\hline 6 & Civic education & $\begin{array}{c}60 \\
(26.0)\end{array}$ & $\begin{array}{c}61 \\
(26.4)\end{array}$ & $\begin{array}{c}49 \\
(21.2)\end{array}$ & $\begin{array}{c}61 \\
(26.4)\end{array}$ & $2.48 \pm 1.14$ & Low extent \\
\hline 7 & Human rights education & $\begin{array}{c}64 \\
(27.7)\end{array}$ & $\begin{array}{c}68 \\
(29.4)\end{array}$ & $\begin{array}{c}44 \\
(19.0)\end{array}$ & $\begin{array}{c}55 \\
(23.8)\end{array}$ & $2.39 \pm 1.13$ & Low extent \\
\hline 8 & Solidarity & $\begin{array}{c}61 \\
(26.4)\end{array}$ & $\begin{array}{c}56 \\
(24.2)\end{array}$ & $\begin{array}{c}56 \\
(24.2)\end{array}$ & $\begin{array}{c}58 \\
(25.1)\end{array}$ & $2.48 \pm 1.13$ & Low extent \\
\hline 9 & $\begin{array}{l}\text { Approaches to conflict } \\
\text { resolution }\end{array}$ & $\begin{array}{c}54 \\
(23.4)\end{array}$ & $\begin{array}{c}51 \\
(22.1)\end{array}$ & $\begin{array}{c}53 \\
(22.9)\end{array}$ & $\begin{array}{c}73 \\
(31.6)\end{array}$ & $2.63 \pm 1.16$ & Low extent \\
\hline 10 & Reconciliation & $\begin{array}{c}47 \\
(20.3)\end{array}$ & $\begin{array}{c}50 \\
(21.6)\end{array}$ & $\begin{array}{c}73 \\
(31.6)\end{array}$ & $\begin{array}{c}61 \\
(26.4)\end{array}$ & $2.64 \pm 1.08$ & Low extent \\
\hline
\end{tabular}




\begin{tabular}{|c|c|c|c|c|c|c|c|}
\hline 11 & Non-violence & $\begin{array}{c}58 \\
(25.1)\end{array}$ & $\begin{array}{c}61 \\
(26.4)\end{array}$ & $\begin{array}{c}59 \\
(25.5)\end{array}$ & $\begin{array}{c}53 \\
(22.9)\end{array}$ & $2.46 \pm 1.10$ & Low extent \\
\hline 12 & Equity of all & $\begin{array}{c}58 \\
(25.1)\end{array}$ & $\begin{array}{c}60 \\
(26.0)\end{array}$ & $\begin{array}{c}54 \\
(23.4)\end{array}$ & $\begin{array}{c}59 \\
(25.5)\end{array}$ & $2.49 \pm 1.13$ & Low extent \\
\hline 13 & Togetherness and unity & $\begin{array}{c}53 \\
(22.9)\end{array}$ & $\begin{array}{c}60 \\
(26.0)\end{array}$ & $\begin{array}{c}53 \\
(22.9)\end{array}$ & $\begin{array}{c}65 \\
(28.1)\end{array}$ & $2.56 \pm 1.13$ & Low extent \\
\hline 14 & Respect for human dignity & $\begin{array}{c}67 \\
(29.0)\end{array}$ & $\begin{array}{c}53 \\
(22.9)\end{array}$ & $\begin{array}{c}54 \\
(23.4)\end{array}$ & $\begin{array}{c}57 \\
(24.7)\end{array}$ & $2.44 \pm 1.15$ & Low extent \\
\hline 15 & Security education & $\begin{array}{c}49 \\
(21.2)\end{array}$ & $\begin{array}{c}51 \\
(22.1)\end{array}$ & $\begin{array}{c}68 \\
(29.4)\end{array}$ & $\begin{array}{c}63 \\
(27.3)\end{array}$ & $2.63 \pm 1.10$ & Low extent \\
\hline 16 & Inter-Ethnic marriages & $\begin{array}{c}60 \\
(26.0)\end{array}$ & $\begin{array}{c}55 \\
(23.8)\end{array}$ & $\begin{array}{c}67 \\
(29.0)\end{array}$ & $\begin{array}{c}49 \\
(21.2)\end{array}$ & $2.45 \pm 1.09$ & Low extent \\
\hline 17 & Social responsibility & $\begin{array}{c}63 \\
(27.3)\end{array}$ & $\begin{array}{c}55 \\
(23.8)\end{array}$ & $\begin{array}{c}64 \\
(27.7)\end{array}$ & $\begin{array}{c}49 \\
(21.2)\end{array}$ & $2.43 \pm 1.10$ & Low extent \\
\hline 18 & $\begin{array}{l}\text { Effective } \\
\text { communication/dialogue }\end{array}$ & $\begin{array}{c}58 \\
(25.1)\end{array}$ & $\begin{array}{c}43 \\
(18.6)\end{array}$ & $\begin{array}{c}67 \\
(29.0)\end{array}$ & $\begin{array}{c}63 \\
(27.3)\end{array}$ & $2.58 \pm 1.14$ & Low extent \\
\hline 19 & National integration & $\begin{array}{c}66 \\
(28.6)\end{array}$ & $\begin{array}{c}55 \\
(23.8)\end{array}$ & $\begin{array}{c}55 \\
(23.8)\end{array}$ & $\begin{array}{c}55 \\
(23.8)\end{array}$ & $2.43 \pm 1.14$ & Low extent \\
\hline & Total & & & & & $2.50 \pm 1.12$ & Low extent \\
\hline
\end{tabular}

Criterion mean $=3.00$;

Key: HI = Highly implemented; I = Implemented; NI =Implemented; HNI = Highly Not implemented

The institutional variation in the implementation of peace and conflict resolution education among the selected tertiary institutions was examined through the test of hypothesis. The researcher hypothesized that there is no significant difference among the institutions represented in the study in terms of the implementation of peace and conflict resolution education. The one-way analysis of variance was used to test the null hypothesis at the .05 alpha level. The result of the analysis, presented in Table 2, revealed that out of the 231 participants, 48, 67, 64, and 52 were lecturers in the universities of Benin, Calabar, Port Harcourt and Uyo respectively. The implementation of the peace and conflict resolution was comparably higher at the University of Calabar, followed by Uyo, Benin and Port Harcourt in that order. However, the analysis of variance indicated that there is no significant institutional variation in the implementation of peace and conflict resolution education in tertiary institutions $(F[3,227]=0.457, p$ $=.712>.05$ ). Based on statistical grounds, the null hypothesis was upheld.The Tukey posthoc test of pairwise multiple comparisons was performed to ascertain whether there are significant differences among the institutions. It was found that there was no significant difference between Calabar and Uyo; Calabar and Benin; Calabar and Port Harcourt; Uyo and Benin; Uyo and Port Harcourt; Benin and Port Harcourt in the extent to which peace and conflict resolution education has been implemented. Thus, the observed mean differences recorded in Table 2 and further depicted in Fig. 1 may have been due to chance.

Table 2. One-way analysis of variance of the institutional variation in the implementation of peace and conflict resolution education in tertiary institutions

\begin{tabular}{lccccc}
\hline Universities & $\mathrm{N}$ & $\overline{\mathrm{X}}$ & $\mathrm{SD}$ & $\mathrm{SE}$ & $95 \%$ CI \\
\hline Benin & 48 & 48.21 & 4.811 & 0.694 & $(46.81,49.61)$ \\
Calabar & 67 & 47.78 & 4.932 & 0.603 & $(46.57,48.98)$ \\
Port Harcourt & 64 & 47.14 & 5.448 & 0.681 & $(45.78,48.5)$ \\
Uyo & 52 & 47.38 & 5.149 & 0.714 & $(45.95,48.82)$ \\
Total & 231 & 47.6 & 5.087 & 0.335 & $(46.94,48.26)$ \\
Source & $\mathrm{SS}$ & $\mathrm{Df}$ & $\mathrm{MS}$ & $\mathrm{F}$ & Sig. \\
Between Groups & 35.76 & 3 & 11.92 & 0.457 & 0.712 \\
Within Groups & 5915.60 & 227 & 26.06 & & \\
Total & 5951.36 & 230 & & & \\
\hline
\end{tabular}




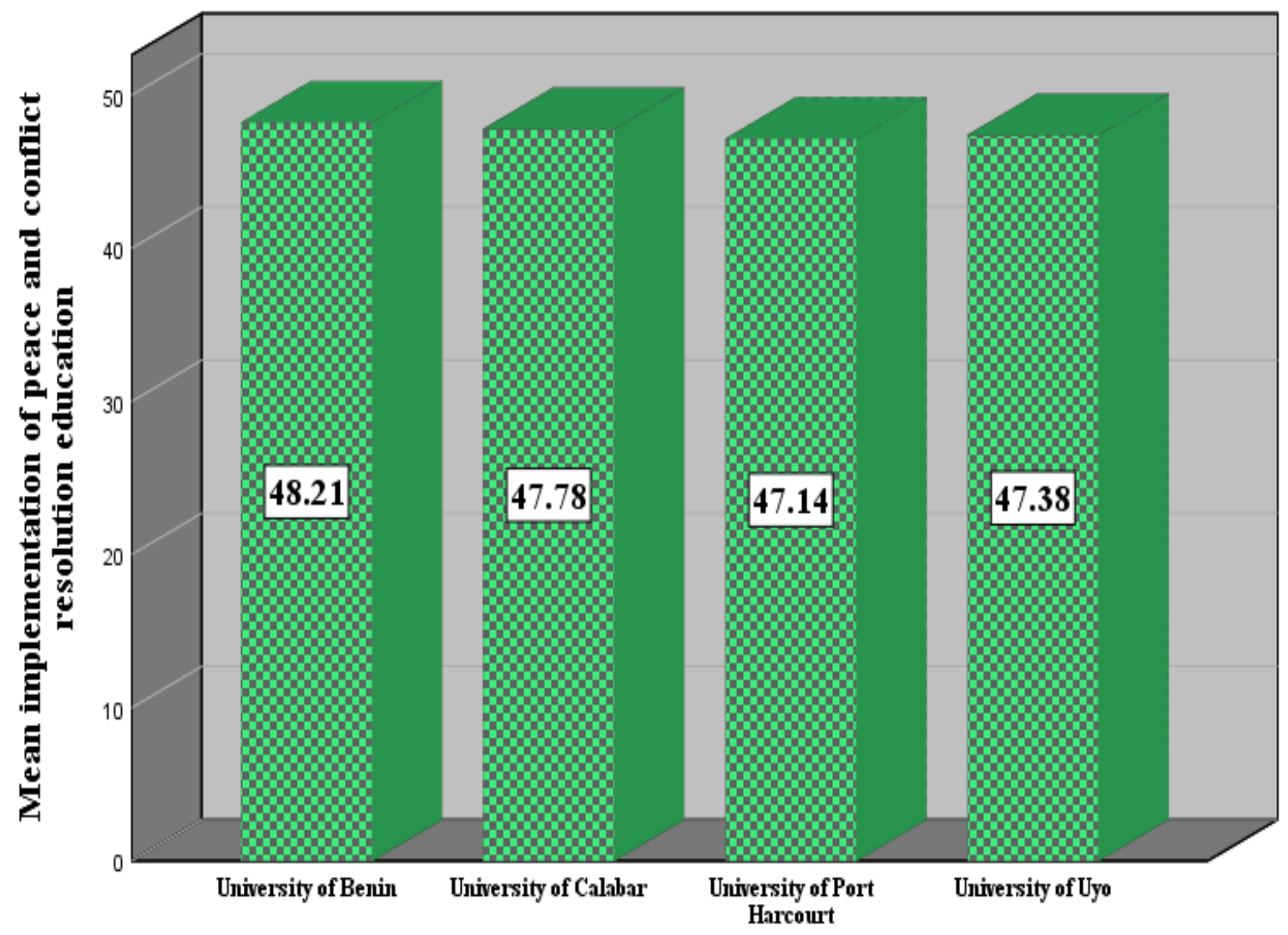

\section{Institutions}

Figure 1. Simple bar chart showing the extent of the implementation of peace and conflict resolution education across four tertiary institutions

\section{Discussion}

This study uncovered a low extent among institutions in the implementation of peace and conflict resolution education in tertiary institutions. This result is due to the low extent in the institutional implementation of education in areas such as love and oneness; religious/ethnic tolerance; sex education; democracy education; justice education; civic education; human rights education; solidarity; approaches to conflict resolution; reconciliation; non-violence; equity of all; togetherness and unity; respect for human dignity; security education; inter-ethnic marriages; social responsibility; effective communication/dialogue and national integration. If education is not offered in crucial areas such as these, then it would not be surprising why the result of this study yielded a low extent. This raises questions on the possible reasons why peace and conflict resolution education are not given a high stake in tertiary institutions amidst the challenges facing the nation.

According to Enaigbe and Igbinoghene (2016), peace and dispute resolution education have yet to take root in Nigerian education due to a lack of understanding of the concept of peace education, as well as its aims and objectives, among policymakers, the general public, and government; and a lack of government acceptance of the peace education concept in West Africa; inadequate funds, particularly funding dedicated to peace education, are a major issue; there is a lack of appropriate and comprehensive peace education curriculum that can be used to meet the needs of the country; parents and guardians are frequently hesitant to support their children and wards in actively participating in peace education programs and activities; the methodologies currently used in formal learning.

To justify the position of this result, the researcher performed a comparison of the institutions under study to determine whether there are differences. Unfortunately, it was discovered that although there are small variations in the management of peace and conflict resolution education across institutions, the differences are negligible. This implies that the low extent of the implementation of peace and conflict resolution education recorded in this study is generalizable across the tertiary institutions in Nigeria. This finding corroborates the results of Ofojebe (2014) which 
also indicated, at the basic education level that aspects of peace education that should be integrated into theNigerian Basic Education for a lasting culture of peace andenvironmental sustainability are not adequately integrated. This implies that the future of peace and conflict resolution in Nigeria is put in doubt. Although the present study faces the limitation of small sample size and geography, the result has implications for policy, practice and further research. The study has been able to expose the position and state of institutional unreadiness to manage conflict and in boosting the conflict management skills of students in higher education. Future researches in related should make efforts to extend the scope beyond the covered areas for a better reflection of realities.

\section{Conclusion}

This study was designed to understand the extent to which tertiary institutions are providing peace and conflict resolution education in Nigeria. Four universities were on target, with quantitative data used to establish a low extent of institutional management of peace and conflict resolution education in Nigeria. This conclusion implies that almost all the tertiary institutions are not offering peace and conflict resolution education to students or are doing so below the level of expectations. This places an open challenge and call to every institutional manager to gird up and work towards improving conflict management and peace promotion in a heterogeneous economy. Based on this conclusion, the following recommendations were made:

i. The government and other stakeholders are strongly urged to develop and fund adequate peace education in the Nigerian tertiary education curriculum. This will go a long way toward providing the necessary facilities, equipment, and resources (both human and materials) for efficient curriculum implementation.

ii. New changes and revisions to the tertiary education curriculum should be widely disseminated via excellent planning and implementation.

iii. School managers and instructors should be properly prepared for the effective realization of this course by regular training, retraining and development of personnel at the classroom level.

iv. Through continuous fora, workshops, seminars, and the strengthening of counseling and advice services, teachers should be exposed to the culture of peace. Peace education must be fostered in a participative way and efficient approaches for teaching must also be used.

v. Courses in peace and conflict resolution should be made a GSS course in Nigerian tertiary educational institutions.

vi. All Departments of social sciences and humanities in Nigerian Universities should run courses on peace and conflict resolution.

vii. Peace and conflict resolution studies should be incorporated into all teacher education programmes to introduce such in secondary education programmes in the country.

viii. The curriculum of peace and conflict resolution studies should be restructured regularly to reflect the changing needs of Nigerian society.

\section{References}

Adesanya, T. O., Osakede, K. O., Ijimakinwa, S. O., \& Ojo, A. D. (2018). Conflict management in tertiary institutions: A study of selected universities in south-western Nigeria. Africa's Public Service Delivery and Performance Review, 6(1), 1-7. https://doi.org/10.4102/apsdpr.v6il.197

Akande, O. D. (2018). Teachers' Perceptions of Peace Education in Nigeria: A Study of Ilorin-South Secondary Schools. The Oriental Anthropologist, 18(2), 255-272. https://doi.org/10.1177/0976343020180206

Akande, O., Kaye, S., \& Rukuni, T. (2021). The Efficacy of Community Peacebuilding in African Communities: Case Studies from Nigeria and Zimbabwe. Journal of Peacebuilding \& Development, 1542316621993035. https://doi.org/10.1177/1542316621993035

Arop, F. O., Owan, V. J., \& Ekpang, M. A. (2018). Administrators' conflict management strategies utilization and job effectiveness of secondary school teachers in Obubra Local Government Area, Cross River State, Nigeria. IIARD International Journal of Economics and Business Management, 4(7), 11-21. https://doi.org/10.5281/zenodo.4320490

Ashraf, M., \& Huma, A. (2020). Professional development needs of primary school teachers in Khyber Pakhtunkhwa to teach peace. Education 3-13, 48(4), 405-412. https://doi.org/10.1080/03004279.2019.1614085 
Brigg, M. (2020). The spatial-relational challenge: Emplacing the spatial turn in peace and conflict studies. Cooperation and Conflict, 55(4), 535-552. https://doi.org/10.1177/0010836720954479

Duncan, L. (2008). Post-conflict behaviour of wild olive baboons: Reconciliation, redirection, and consolation. Ethology, 104, 126-147. https://doi.org/10.1111/j.1439-0310.1998.tb00057.x

Enaigbe, P., \& Igbinoghene, N. (2016). Challenges of managing and planning peace education and peace culture in Nigeria. African Research Reviews, 10(4), 83-92. https://doi.org/10.4314/afrrev.v10i4.6

Felbab-Brown, V. (2020). As conflict intensifies in Nigeria's North East, so too does reliance on troubled militias. https://brook.gs/3bS9rgA

Global Terrorism Index (2015). Measuring and Understanding the Impact of Terrorism. Institute for Economics and Peace.

Harris, I. (2004). Peace education theory. Journal of Peace Education, 1(1), 5-20. https://doi.org/10.1080/1740020032000178276

Huda, M., Nor Muhamad, N. H., Isyanto, P., Muhamat, R., Marni, N., Ahmad Kilani, M., \& Safar, J. (2020). Building harmony in a diverse society: insights from practical wisdom. International Journal of Ethics and Systems, 36(2), 149-165. https://doi.org/10.1108/IJOES-11-2017-0208

Jeong, H. W. (2017). Peace and conflict studies: An introduction. Taylor \& Francis. https://doi.org/10.4324/9781315247236

Kishino, H., \& Takahashi, T. (2019). Global citizenship development: Effects of study abroad and other factors. Journal of International Students, 9(2), 535-559. https://doi.org/10.32674/jis.v9i2.390

Maduewesi, B. U. (2019). Lecturers' Perception of the Use of Teacher Education Curriculum Content for Conflict Resolution. International Journal of Research Development, 11(1), 1-9.

McLeod, L., \& O’Reilly, M. (2019). Critical peace and conflict studies: feminist interventions. Peacebuilding, 7(2), 127-145. https://doi.org/10.1080/21647259.2019.1588457

Miall, H., Ramsbotham, O., \& Woodhouse, T. (2005). Contemporary conflict resolution. Polity Press.

Mishra, L. (2011). Pre-service teacher training for peace education. International Journal of Peace and Development Studies, 2(7), 203-210.

Nwaubani, O. O., \& Okafor, O. S. (2015). Assessing the Moral Relevance of Peace Education Contents in the Basic Education Social Studies Curricula for Effective Citizenship Participation in Nigeria. Journal of education and practice, 6(13), 79-87.

Ofojebe, W. N. (2014). Integrating peace education into the Nigerian Basic Education curriculum for lasting peace and environmental sustainability. European Scientific Journal, 10, 154-170. https://bit.ly/3ukCEHp

Okeke, C. (2018). Perception of Teachers on the Influence of Peace Education in the South-East Nigerian Secondary Schools. International Journal of Operational Research in Management, Social Sciences \& Education, 4(1), 222-236.

Omeje, K. (2015). Promoting peace and conflict-sensitive higher education in sub-Saharan Africa. African Conflict and Peacebuilding Review, 5(2), 33-56. https://doi.org/10.2979/africonfpeacrevi.5.2.33

Owan, V. J. (2018). Conflict management strategies and secondary school teachers' job effectiveness in Obubra Local Government Area of Cross River State, Nigeria. B.Ed. Project, (University of Calabar, Nigeria). https://doi.org/10.13140/RG.2.2.35015.55200

Owan, V. J., \& Agunwa, J. N. (2019). Principals' administrative competence and teachers' work performance in secondary schools in Calabar Education Zone of Cross River State, Nigeria. Humanities and Social Sciences Letters, 7(1), 20-28. https://doi.org/10.18488/journal.73.2019.71.20.28

Page, J. S. (2008). Peace education: Exploring ethical and philosophical foundations. Charlotte: Information Age Publishing.

Sani, A. (2013). Nigerian Curriculum and National Integration: Issues and Challenges. British Journal of Education, Society \& Behavioural Science, 4(3), 309-317. https://doi.org/10.9734/BJESBS/2014/6339 
Shumba, O., Manokore, V., Silitshena, P., Sango, G., Dhlomo, T., \& Mhondoro, K. (2005). Analysis of opportunities and Gaps in Teacher Education Curriculum on growing up and survival maturation: Zimbabwe Journal of Educational Research, 1(2), 12-22.

Smoker, P., \& Groff, L. (1996). Creating global-local cultures of peace. Peace and Conflict Studies, $3(1), 3$. https://doi.org/10.46743/1082-7307/1996.1170

Sulaiman, K. D. O. (2016). Religious violence in contemporary Nigeria: Implications and options for peace and stability order. Journal for the Study of Religion, 29(1), 85-103.

Ubogu, R. (2016). Peace Education in Secondary Schools: A Strategic Tool for Peace Building and Peace Culture in Nigeria. Journal of Education and Practice, 7(14), 88-92.

UNDP (2016). Preventing Violent Extremism through Inclusive Development and the Promotion of Tolerance and Respect for Diversity. A Discussion Paper on a Development Response to Addressing Radicalization and Violent Extremism, March 2016.

Woiwode, C., Schäpke, N., Bina, O., Veciana, S., Kunze, I., Parodi, O., \& Wamsler, C. (2021). Inner transformation to sustainability as a deep leverage point: fostering new avenues for change through dialogue and reflection. Sustainability Science, 1-18. https://doi.org/10.1007/s11625-020-00882-y

Yunus, S. (2020). Direct integration of peace education and its effects on students' understanding of peace. Talent Development \& Excellence, 12(1), 2112-2120.

\section{Copyrights}

Copyright for this article is retained by the author(s), with first publication rights granted to the journal.

This is an open-access article distributed under the terms and conditions of the Creative Commons Attribution license (http://creativecommons.org/licenses/by/4.0/). 